\title{
DARIUSZ FuCHS
}

\section{DOPUSZCZALNOŚĆ ROSZCZEŃ REGRESOWYCH INSTYTUCJI ZABEZPIECZENIA SPOŁECZNEGO Z PAŃSTW UNII EUROPEJSKIEJ WOBEC POLSKIEGO UBEZPIECZYCIELA OC UBEZPIECZONEGO - ODPOWIEDZIALNEGO ZA SZKODĘ}

\section{WSTĘP}

Coraz częściej w praktyce ubezpieczeniowej występują roszczenia, które ze swej istoty są powiązane $\mathrm{z}$ więcej niż jednym obszarem prawnym; zawierają element międzynarodowy. Dotychczas najczęstszym przykładem tego rodzaju był wypadek komunikacyjny, gdzie prawo ojczyste sprawcy nie pokrywało się z lex loci delicti. Jednakże wraz z uzyskaniem członkostwa Polski w Unii Europejskiej na znaczeniu zyskały regulacje o charakterze ponadnarodowym (prawo tworzone przez regionalne organizacje międzynarodowe. Szczególnym tego przykładem jest rozporządzenie jako określony rodzajowo akt wspólnotowego prawa wtórnego. Fakt iż co do zasady rozporządzenie (co nie oznacza, iż tak być nie może) nie wymaga koniecznej (jak w przypadku aktegorii tzw. dyrektyw horyzontalnych) implementacji ma nie tylko korzystne dla jednolitości stosowania w całej Unii następstwa. Czasami fakt ten rodzi problemy interpretacyjne a przy okazji uwypukla różnice pomiędzy analogicznymi instytucjami prawnymi, obowiązującymi w różnych państwach członkowskich Unii Europejskiej. 
Takim właśnie przykładem który zarazem wskazuje konieczność pilnych zmian w regulacji rodzimej jest zagadnienie regresu kierowanego przez instytucję zabezpieczenia społecznego z siedzibą w państwie członkowskim UE do ubezpieczyciela OC odpowiedzialnego za szkodę (który najprawdopodobniej jest także sprawcą wpierw zaistniałego zdarzenia losowego - wypadku ją powodującego) co statystycznie najczęściej dotyczy z oczywistych powodów wypadku komunikacyjnego, chociaż wcale tak być z oczywistych względów nie musi.

W takim ujęciu należy zwrócić uwagę, iż nie wystarczy analiza jedynie rozwiązań prawnych, które się tradycyjnie uznaje za domenę prawa ubezpieczeń gospodarczych ale należy niewątpliwie (oprócz przydatnej analizy prawnoporównawczej porządków materialnych poszczególnych państw członkowskich $\mathrm{UE}^{1}$ ) sięgnąć do podstawowej regulacji odnoszącej się do koordynacji systemów zabezpieczenia w poszczególnych państwach członkowskich. Przy tej okazji należy podkreślić, iż wbrew obiegowej opinii rozporządzenia wspólnotowe jako źródła prawa wtórnego nie są wcale jednolitą kategorią pojęciową. Przede wszystkim należy zwrócić uwagę, iż zgodnie z rozpowszechnionym, generalnym poglądem doktryny, mającym swe oparcie w orzecznictwie wspólnotowym zasadniczą cechą takiego aktu prawnego jest fakt jego obowiązywania adresatów bez konieczności dokonywania implementacji (nazywanej także, niezbyt szczęśliwie: transpozycją²) w porządku prawnym danego państwa członkowskiego ${ }^{3}$.

W praktyce prawotwórczej, co zostało zaakceptowane przez doktrynę, funkcjonuje także podział rozporządzeń wspólnotowych na ogólne i wykonawcze (o charakterze technicznym, które doprecyzowują normy tych pierwszych). Jest to kwestia istotna dla omawianej materii, gdyż system zabezpieczenia społecznego w Unii Europejskiej opiera się przede wszystkim na kilku podstawowoych aktach prawnych, a mianowicie:

${ }^{1}$ Co jednak z przyczyn oczywistych wykracza poza ramy niniejszego artykułu

${ }^{2} \mathrm{Na}$ temat oceny pojęcia transpozycji prawa wspólnotowego, por. E. KowALEwSKI, D. Fuchs, M. ZIEMIAK, Implementacja dyrektywy reasekuracyjnej do polskiego porzadku prawnego, «Prawo Asekuracyjne» 59.2/2009, s. 15 i n.

${ }^{3}$ C. Mıк, Europejskie prawo wspólnotowe. Zagadnienia teorii i praktyki, I, Warszawa 2000, s. $651 \mathrm{i} \mathrm{n}$. 
1/ Rozporządzenie Rady (EWG) nr 1408/71 z dnia 14 czerwca 1971 r. w sprawie stosowania systemów zabezpieczenia społecznego do pracowników najemnych, osób prowadzących działalność na własny rachunek i do członków ich rodzin przemieszczających się we Wspólnocie ${ }^{4}$ oraz Roporządzenia Rady (EWG) nr 574/72 z 21 marca 1973r. w sprawie wykonania rozporządzenia (EWG) $\mathrm{nr}$ 1408/71 w sprawie stosowania systemów zabezpieczenia społecznego do pracowników najemnych, osób prowadzących działalność na własny rachunek i do członków ich rodzin przemieszczających się we Wspólnocie ${ }^{5}$ (tzw. rozporządzenie wykonawcze)

2/ Rozporządzenie Parlamentu Europejskiego i Rady (WE) nr 883/2004 z dnia 29 kwietnia 2004r. w sprawie koordynacji systemów zabezpieczenia społecznego (do chwili obecnej brak adekwatnego rozporządzenia wykonawczego).

W nawiązaniu do tego podzialu w literaturze przedmiotu funkjonuje zgodny pogląd, iż stosowanie rozporządzeń ogólnych (takich jak Rozporządzenie 1408/71 oraz Rozporządzenie 883/2004) jest uzależnione od wejścia w życie i obowiązywania rozporządzeń wykonawczych ${ }^{6}$. Tym samym dopóki, dopóty rozporządzenia wykonanwczego brak, dany akt prawny - rozporządzenie o charakterze ogólnym nie wchodzi w życie. W związku z powyższym należy przyjąć, iż w omawianej materii wciąż obowiązuje Rozporządzenie 1408/71.

II. ZAKRES PRZEDMIOTOWY REGULACJI ROZPORZĄDZENIA 1409/71 ORAZ ROZPORZĄDZENIA 883/2004

Odnosząc się do zakresu zastosowania obu rozporządzeń (tj.: Rozporządzenie 1409/71 oraz Rozporządzenia 574/72) należy podkreślić znaczenie artykułu 4 rozporządzenia 1408/71, gdzie stwierdza się,

${ }^{4}$ Dz, Urz. WE L z 1997 r. 28 ze zm. Por. tekst jednolity, przygotowany przez Departament Prawny KUP w marcu 2001 r., maszynopis powielony

5 Dz. Urz. WE L z 1997 r. 28 ze zm.

6 D. Wojtczak, [w:] Stosowanie prawa wspólnotowego w prawie wewnętrznym z uwzględnieniem prawa polskiego, red. D. KornoBis-RomanowsKa, Warszawa 2004, s. 68 . 
iż przepisy dalsze obejmują 8 następujących rodzajów świadczeń z tytułu: choroby i macierzyństwa, inwalidztwa, starości, śmierci żywiciela, wypadku przy pracy i choroby zawodowej, bezrobocia, jak również zasiłki pogrzebowe oraz rodzinne. Artykuł 7 tegoż rozporządzenia przyznaje pierwszeństwo wymienionym tam konwencjom i normom międzynarodowym, z których pierwszorzędne znaczenie mają Umowy Tymczasowe w zakresie Zabezpieczenia Socjalnego Rady Europy z 1953 r., jeżeli zostały ratyfikowane przez państwa członkowskie 7.

Zarazem należy podkreślić, iż $\mathrm{w}$ art. 8 podkreślono prymat Rozporządzenia 1409/71, a umowy bilateralne pomiędzy państwami członkowskimi powinny być zawierane w duchu i z poszanowaniem niniejszego rozporządzenia. Tym bardziej zasada ta musi obowiązywać w stosunku do umów zawartych jeszcze przed data akcesji Polski do UE, a wobec tego także wobec takich umów z państwami członkowskimi należy uznać przymat prawa wspólnotowego, w tym przede wszystkim Rozporządzenia 1409/71.

Na marginesie, ze względu na ratyfikację przez Rzeczpospolitą Polską innej konwencji Rady Europy: Europejskiej Karty Socjalnej, należy w tym kontekście wspomnieć o zasadach tam zawartych, które również ipso iure et facto są odzwierciedlone w poszczególnych systemach ubezpieczeniowych państw członkowskich Unii Europejskiej ${ }^{8}$.

Jak wynika z analizy Karty oraz Rozporządzeń, również te reguły są inkorporowane do omawianych rozporządzeń, co pozwala wnosić o ich zasadniczej zgodności z ratio conventionis Europejskiej Karty Socjalnej, ergo: praktycznym dostosowywaniu się polskiego ustawodawstwa do wymogów Unii Europejskiej, niezależnie od faktu członkostwa w UE i faktycznie: przed datą uzyskania statusu państwa członkowskiego przez Rzeczpospolita Polską?

7 Por. R. Henczel, J. Maciejewska, Podstawowe dokumenty Rady Europy z dziedziny polityki spolecznej, Warszawa 1997, s. 294 i n.

${ }^{8}$ Por. R. Henczel, J. Maciejewska, op. cit., s. 15; dalsze uwagi uwzględniają również tekst Karty zawarty w tejże publikacji, s. 18 i n.

9 Szczegółowe rozważania w tym zakresie D. Fuchs, Zarys prawa ubezpieczeń socjalnych, op. cit., s. $27-33$. 
III. REGRES W UJĘCIU PRAWA WSPÓLNOTOWEGO NA PRZYKŁADZIE ART. 93 UST. 1 ROZPORZĄDZENIA 1408/71

Zgodnie z dostępną polską wersją art. 93 ust.1 Rozporządzenia 1408/71, odnosząc się do uprawnień ,instytucji zobowiązanych do wypłaty w stosunku do osób trzecich, ponoszących odpowiedzialność"10, stanowi, że:

„Jeżeli osoba korzysta ze świadczeń na mocy ustawodawstwa Państwa członkowskiego, z tytułu wynagrodzenia szkody powstałej na skutek zdarzeń zaistniałych na terytorium innego państwa członkowskiego, ewentualne prawa instytucji zobowiązanej do wypłaty w stosunku do osoby trzeciej, zobowiązanej do wynagrodzenia szkody, uregulowane są nastepująco:

a/ o ile instytucja zobowiązana do wypłaty wstapiła, na mocy stosowanego przez nią ustawodawstwa, w prawa, jakie świadczeniobiorcy przysługują w stosunku do osób trzecich, subrogację uznaje każde państwo członkowskie;

b/ o ile instytucja zobowiązana do wypłaty ma bezpośrednie roszczenie wobec osoby trzeciej, roszczenie to jest uznawane przez każde Państwo członkowskie."

Wstępnie należy podkreślić, iż instytucja subrogacji jest powszechnie znana w ubezpieczeniach, czego rodzimym przykładem, obowiązującym de lege lata jedynie w odniesieniu do roszczeń wynikających z umowy ubezpieczenia, jest art. 828 k.c., szczególnie w treści przewidzianej paragrafem 1.

Warto w tym miejscu podkreślić, iż w znanej polskiemu prawu konstrukcji subrogacji występuje tutaj tzw. subrogacja z mocy prawa, w oparciu właśnie o brzmienie art. 828 § 1 k.c., gdyż przepis ten stanowi in capita, iż jeżeli strony inaczej się nie umówiły, to następuje przejście roszczeń o takim charakterze ${ }^{11}$. Stanowisko powyższe potwierdza również ugruntowane orzecznictwo SN, który to już w 1970

${ }^{10}$ Jak określono w tytule tego przepisu prawa wspólnotowego.

11 Por. M. Orlicki, J. Pokrzywniak., Nowelizacja Kodeksu Cywilnego, Warszawa 2007, s. 123, a także W. KunowsKi, Przelew wierzytelności w prawie prywatnym międzynarodowym, Zakamycze 2005, s. 26 oraz przyp. 21. 
roku $^{12}$ wyraził pogląd, iż dla subrogacji nie jest istotna treść umowy ubezpieczenia (i odpowiednio reasekuracji), gdyż dla uzyskania możliwości dochodzenia roszczeń przez ubezpieczyciela od sprawcy szkody wystarczającym jest $828 \S 1$ k.c.

Z powyższego można wobec tego wywieść bardziej ogólną konsekwencję, iż jeżeli prawo właściwe danego stosunku przewiduje konstrukcję porównywalną do przykładu z rodzimego k.c., to mamy do czynienia z przykładem subrogacji z mocy prawa, a nie "typowego" przelewu roszczeń ${ }^{13}$.

Dla prawidłowej oceny charakteru prawnego normy, przy założeniu, uzasadnionym powyżej, iż obowiązuje w interesującym nas zakresie Rozporządzenie 1408/71, niewątpliwie jeszcze raz należy podkreślić, iż zasadniczy charakter ma ogólna koncepcja regulacji prawa wspólnotowego, jakąjest koncepcja koordynacji systemów krajowych, a nie ich ujednolicanie.

Jednakże powyższy wniosek nie oznacza, zdaniem piszącego, iż Rozporządzenie 1408/71 nie może zawierać norm, które wyposażają podmioty indywidualne w określone uprawnienia, jakim może być uprawnienie wynikające z subrogacji. Tym samym nie można wywodzić bezpośrednio uprawnienia z subrogacji, jeżeli prawo rodzime instytucji, która się na to powołuje, takiego rozwiązania nie przewiduje.

Jeżeli jednak jest inaczej (tzn. gdy system prawny danego państwa członkowskiego takie rozwiązanie de lege lata przewiduje), to wówczas art. 91 ust.1 Rozporządzenia, mając bezpośredni skutek we wszystkich państwach członkowskich (a więc, od daty uzyskania członkostwa w UE i wejścia ich w życie, także: Rzeczpospolitej Polskiej) zobowiązuje do respektowania tego roszczenia.

Tym samym należy się zgodzić z poglądem, iż prawo polskie (pojmowane jako system prawny wewnętrzny, bez uwzględnienia koniecz-

12 Wyrok SN z 18.05.1970 I CR 58/70 «OSN» 1971 z. 5, poz 86, cyt. w E. KoWALEWSKI, Umowa ubezpieczenia, Bydgoszcz-Toruń 2002, str. 146

13 Szerzej D. Fuchs, Uwagi dotyczqce roszczeń regresowych ubezpieczyciela wobec odpowiedzialnego za szkodę na przykładzie roszczeń wobec zarzqdcy nieruchomości wspólnej, «Rozprawy Ubezpieczeniowe» 7.2/2009, w druku. 
ności stosowania acquis w razie, gdy dany stosunek prawny wykazuje związek z obszarem prawnym innego państwa członkowskiego UE, lub, ujmując kwestię w sposób bardziej ogólny: gdy dany stosunek prawny wykazuje cechę transgraniczności, przez co odziaływuje na sytuację prawną podmiotów z różnych państw czlonkowskich) nie jest właściwe dla oceny, czy subrogacja w przedmiotowych przypadkach zachodzi czy też nie.

A rebours, w sytuacji, gdyby z analogicznym roszczeniem wystapił obywatel polski, który podlegał leczeniu w rodzimym zakładzie opieki zdrowotnej, a koszty tego leczenia byłyby dla przykładu finansowane z NFZ, to de lege lata (niezależnie od ewentualnych, projektowanych w prawie polskim rozwiązań), wobec braku odpowiedniej podstawy materialno-prawnej, nie mógłby ten podmiot spodziewać się sukcesu, wywodząc swoje roszczenie z art. 93 ust.1 Rozporządzenia 1408/71 wobec. np. ubezpieczyciela sprawcy szkody z siedzibą w Hiszpanii. Analogiczny efekt występowałby w sytuacji, gdy to rodzimy zakład opieki zdrowotnej wystapiłby $\mathrm{z}$ takim roszczeniem $\mathrm{z}$ tych samych zresztą powodów, tzn. braku normy polskiego prawa materialnego, która to takie uprawnienie kreowałaby po stronie instytucji zabezpieczenia społecznego, która pokryła koszty. W konsekwencji podobnie nie podlegałoby uwzględnieniu roszczenie Narodowego Funduszu Zdrowia w opisanych okolicznościach stanu faktycznego.

Na marginesie powyższych wywodów należy zwrócić uwagę, iż $\mathrm{w}$ analogiczny sposób, zdaniem piszącego, jest skonstruowana norma art. 18 Rozporządzenia (WE) NR 864/2007 PARLAMENTU EUROPEJSKIEGO I RADY z dnia 11 lipca 2007 r. dotyczące prawa właściwego dla zobowiązań pozaumownych („Rzym II”), które wszedł co do zasady w życie życie z dniem 11 stycznia 2009 r. Art. 18 tego aktu prawnego, zatytułowany „Bezpośrednie powództwo przeciwko ubezpieczycielowi osoby odpowiedzialnej" przewiduje:

Osoba, która poniosła szkodę, może wystąpić z roszczeniem o odszkodowanie bezpośrednio przeciwko ubezpieczycielowi osoby odpowiedzialnej, jeżeli przewiduje to prawo właściwe dla zobowiązania pozaumownego lub prawo właściwe dla umowy ubezpieczeniowej." 
Tym samym sposób regulacji, obecny w art. 93 ust. 1 Rozporządzenia 1408/71 nie może być uznany za wyjątkowy, czy też unikatowy dla praktyki legislacyjnej organów wspólnotowych.

IV. RELACJA REGULACJI NORM UMÓW MIĘDZYNARODOWYCH, ZAWARTYCH PRZEZ Polskę PRZED DATA CZlONKOSTWA W UE W STOSUNKU DO FAKTU UZYSKANIA CZŁONKOSTWA RP w UE, A W SZCZEGÓLNOŚCI DO ART. 93 UST. 1 ROZPORZĄDZENIA 1408/71

$\mathrm{Na}$ wstępie, dokonując oceny znaczenia umów międzynarodowych, dotyczących zabezpieczenia socjalnego dla relacji wobec prawa regresu na podstawie art. 93 ust.1 Rozporządzenia 1408/71, szczególnie wówczas, gdy takie umowy międzynarodowe zostały ratyfikowane przed data czlonkostwa Rzeczpospolitej Polskiej w UE, należy zwrócić uwagę, że Traktaty ustanawiające Wspólnoty Europejskie i w konsekwencji Unię Europejską, nie zawierają ogólnych postanowień, rozstrzygających kolizję materialno-prawną między prawem Unii a regulacjami poszczególnych państw ${ }^{14}$. Pierwszeństwo porządku jurydycznego Unii opiera się przede wszystkim na konsekwentnej linii orzeczniczej Europejskiego Trybunału Sprawiedliwości i jest reprezentowane w literaturze prawa wspólnotowego $^{15}$.

Zdaniem piszącego, ponieważ te umowy, zgodnie z treścią art. 87 Konstytucji RP, będą zaliczane do tzw. powszechnie obowiązujących źródeł prawa, tym samym powinny być oceniane, w porównaniu $\mathrm{z}$ re-

${ }^{14}$ R. Dehousse, Comparing national and EC Law. The problem of the level of analysis, «EUI LAW» $1994 \mathrm{nr}$ 3, s.6 i n.

${ }^{15}$ Np. S. RUDNICKI, Problem harmonizowania prawa wewnętrznego państw Wspólnoty Europejskiej, «Przegląd Sądowy» 2.7-8/1992, s. 24-25; I. Koppen, The Role of the European Court of Justice in the Development of the European Community Enviromental Policy, «EUI EPU» 18/1992, s. 7-12; A. O’NeILL, The Goverment of Judges. The Impact of the European Court of Justice on the Constitutional Order of the United Kingdom, «EUI LAW» 1993 nr 3, s. 12-28; J. Konte (red.), 'Primus Inter Pares': The European Court and National Courts. The Follow up by National Courts of Preliminary Rulings ex art. 177 of the Treaty of Rome: A Report on the Situation in the Netherlands, «EUI LAW» $1990 \mathrm{nr}$ 6, s. 5-7; A. Michael, op. cit., s. 80 i n.; J. Heidinger, A. Hubalek, M. PramberGER, Introduction to EU Law, s. 47-58. 
gulacji acquis, analogicznie jak inne akty prawa stanowionego, np. ustawy. Z tego też powodu, jeżeli rozpatruje się stan faktyczny w horyzoncie czasowym po wejściu Rzeczpospolitej Polskiej do Unii Europejskiej, to należy uznać zasadę prymatu prawa europejskiego, zaliczanego tym bardziej, do tak szczególnej kategorii, jak rozporządzenia wspólnotowe, które opisano powyżej.

Konsekwentnie należy przypomnieć, iż zgodnie z tym ETS stwierdził, iż w przypadku niedostosowania prawa wewnętrznego do dyrektywy w określonych sytuacjach, jednostka będzie mogła kształtować swe prawa i obowiązki według określonego aktu prawnego Wspólnoty ${ }^{16}$. Tym bardziej ta konsekwencja powinna obowiązywać w przypadku różnic z treścią rozporządzenia. Dalej wypada przypomnieć, iż w przypadku niezgodności prawa Unii z podstawowymi zasadami konstytucyjnymi państwa członkowskiego, prymat przyznaje się powszechnie droit communautaire. Kategoryczne potwierdzenie znalazła ta zasada w sprawie Costa v. ENEL ${ }^{17}$, gdzie Trybunał wyraził tezę, iż państwa członkowskie przekazały definitywnie Wspólnocie określony Traktatem zakres suwerenności. Proces ten nie może być zahamowany ani też odwrócony.

Analogiczne stanowisko Trybunał zajął w wielu kolejnych orzeczeniach, czego sztandarowym przykładem jest Simmenthal $\mathrm{II}^{18}$. kiedy to między innymi wyłączono stosowanie zasady lex posterior derogat legi priori w przypadku zbiegu normy wspólnotowej z krajową.

Tym samym nie ma szczególnych podstaw do poszczególnych umów bilateralnych odnoszących się do problematyki zabezpieczenia społecz-

16 Sprawa Van Dwyn 41/74 Rec. 1337 - orzeczenie przytoczone przez I. Hykawy, Dyrektywa jako specyficzny środek harmonizacji prawa w Europejskiej Wspólnocie Gospodarczej, «PUG» 1993 nr 8-9, s. 5; T. Кот, Harmonizacja Prawa w Unii Europejskiej, «KPP» 4.4/1995, s. 556-557.

${ }^{17}$ Case 6/64(1964) ECR 585; K. Bradley, Law and Institutions of the European Communities, Firenze 1994, s. 36-40; W. CZAPLIŃSKI, Akty prawne wspólnot europejskich w orzecznictwie Trybunału Sprawiedliwości, [w:] Prawo międzynarodowe i wspólnotowe w wewnętrznym porzqdku prawnym, red. M. KRUK, Warszawa 1997, s. 193-195.

18 Case 106/77(1978) ECR 629; E. PIONTEK, Obowiqzywanie prawa wspólnotowego, «Palestra» 40.1-2/1995, s. 88; por. F. Galsten, C. Mik, op. cit., s.169-170; G. Druesne, op. cit., s.18; K. BRADLEY, Law and Institutions, cit., s. 41-44. 
nego, których Rzeczpospolita Polska jest członkiem, gdyż ewentualna regulacja bilateralna (lub jej brak) w zakresie roszczeń regresowych, nie powinna mieć zastosowania do roszczeń powstałych po dacie wstapienia Rzeczpospolitej do UE. Inny wniosek prowadziłby zresztą do podważenia samej istoty regulacji Rozporządzenia 1408/71 i Rozporządzenia wykonawczego, jakim jest funkcja koordynacyjna systemów zabezpieczenia społecznego, tym bardziej, iż w opinii piszącego, uzasadniona jest teza o tym, iż do czasu promulgacji i wejścia w życie rozporządzenia wykonawczego do Rozporządzenia 883/2004 obowiązuje poprzednie, tj.: Rozporządzenie 1408/71.

\section{Podsumowanie}

Przeprowadzona powyżej analiza skłania do wniosku, iż rodzimy prawodawca jak najszybciej powinien dokonać odpowiedniej modyfikacji systemu zabezpieczenia społecznego, tak aby umożliwić polskim instytucjom dochodzenie roszczeń regresowych, zgodnie z art. 91 ust.1 Rozporządzenia 1408/71. Utrzymywanie w dalszym ciagu obecnego stanu prawnego prowadzi z jednej strony do braku symetrii, porównując systemy prawne innych (np. Austria, RFN) państw członkowskich Unii Europejskiej. Analogiczny problem występuje zresztą w stosunku do innych państw objętych Europejskim Obszarem Gospodarczym, do których regulacja art.91 ust. 1 Rozporządzenia 1408/71 ma także zastosowanie.

$\mathrm{Z}$ drugiej strony wobec braku odpowiedniej regulacji w prawie merytorycznym, prowadzi do rozbieżności orzeczniczej polskich sądów powszechnych, które w swej praktyce także odwołują się do właściwości deliktowej prawa polskiego, odmawiając honorowania regresu europejskiej instytucji zabezpieczenia społecznego.

Wobec specyfiki źródła prawa, jakim jest rozporządzenie wspólnotowe, nie ma potrzeby dokonywać jakichkolwiek modyfikacji treści już zawartych przez Rzeczpospolitą Polską umów bilateralnych z tymi państwami, które są zarazem członkami UE. W tych okolicznościach obowiązująca regulacja art. 93 ust.1 Rozporządzenia 1408/71 jest w zupełności wystarczająca i stanowi niezbędną zachętę dla poszcze- 
gólnych prawodawców krajowych do wprowadzania takiej instytucji we własnym porządku prawnym.

Wypada podkreślić, że Art. 93 ust. 1 Rozporządzenia 1408/71 nie kreuje samoistnie subrogacji z mocy prawa wspólnotowego po stronie zakładu opieki zdrowotnej (vel: kasy chorych lub zakładu ubezpieczeń zdrowotnych) wobec sprawcy szkody lub jego ubezpieczyciela, a jedynie gwarantuje, ze względu na przyjętą przez prawodawcę wspólnotowego koncepcję koordynacji krajowych systemów zabezpieczenia społecznego, respektowanie takiego prawa, jeżeli prawo właściwe je przyznaje danej instytucji.

Ultime, wniosek odmienny prowadziłby w praktyce do dezintegracji wspólnotowego systemu zabezpieczenia społecznego, czemu przecież od kilkudziesięciu lat prawodawca wspólnotowy stara się przeciwdziałać. Wniosek odmienny byłby hipotetycznie możliwy, gdyby przywołana norma art. 93 ust.1 Rozporządzenia 1408/71 była niejasna, niekonkretna lub zbyt ogólna. Zdaniem piszącego za uzasadnioną należy przyjąć tezę, iż jest wprost przeciwnie. Na zakończenie należy podkreślić, iż w oparciu o przywołane orzecznictwo ETS - u przyjąć, iż $\mathrm{w}$ razie kolizji pomiędzy regulacją międzynarodowych umów bilateralnych a Rozporządzeniem 1408/71, należy co do zasady przyznać prymat prawu wspólnotowemu, zgodnie z powszechną także doktrynie zasadą pierwszeństwa acquis communautaire (droit communautaire).

\author{
Admissibility of Claims of Social Security Institutions \\ of the European Union Countries to the Polish Insurer \\ of Civil Liability INSURED WHO IS \\ Responsible for THE DAMAge
}

\title{
Summary
}

The paper contains a general overview of the legal nature and the specific character of the recourse under the EU regulations on the application of social security schemes to employed persons and their families moving within the EU concerning civil liability insurer. 
It was underlined specific position of the social insurance institutions form EU Members versus Polish insurer. It was expressed that necessity of amendment of the Polish insurance regulation to create a base for recourse as in EU regulation. 